\title{
Agronomical and physiological characters of kaffir lime (Citrus hystrix DC) seedling under artificial shading and pruning
}

\author{
Rahmat Budiarto', Roedhy Poerwanto ${ }^{2,3 *}$, Edi Santosa ${ }^{2,3}$, Darda Efendi ${ }^{2,3}$, Andria Agusta ${ }^{4}$ \\ ${ }^{1}$ Graduate School of Bogor Agricultural University, Bogor, 16680, Indonesia, ${ }^{2}$ Department of Agronomy and Horticulture, Bogor Agricultural \\ University, Indonesia, ${ }^{3}$ Center for Tropical Horticulture Studies, Bogor Agricultural University, Indonesia, ${ }^{4}$ Research Center for Biology, \\ Indonesian Institute of Science, Bogor, 16911, Indonesia
}

\section{A B S T R A C T}

Kaffir lime (Citrus hystrix DC) is a minor citrus and its leaves are locally used for spices and essential oils. This study aimed to evaluate agronomical and physiological characters of kaffir lime seedling under modified cultural practices in order to improve leaf production. Shading and pruning were applied on five-month-old seedling during the rainy season, November 2017 to March 2018 in Bogor, Indonesia. The results showed that shading significantly improved the plant growth by $84 \%$, and leaf number by $37 \%$. Pruning treatment reduced the plant height by $8 \%$ and increased the shoot number by $20 \%$. However, leaf production was more influenced by shading rather than pruning, with an increase for about $59 \%$ than control. This study also revealed a significant improvement on photosynthetic rate, stomatal conductance and water use efficiency on shaded lime for about $13 \%, 8 \%$ and $14 \%$, respectively. Leaf pigment was also altered in response to shading, i.e the increasing chlorophyll B by $23 \%$ and the reduction anthocyanin by $38 \%$ on shaded lime. Mild shading with $24 \%$ light reduction is recommended to gain the leaf production of kaffir lime seedling.

Keywords: Chlorophyll; Pinching; Photosynthesis; Leaf production; Stomatal conductance

\section{INTRODUCTION}

Citrus has been recorded to be cultivated by the ancestors since $2100 \mathrm{BC}$ so that it was called as ancient crop (Moore, 2001). Citrus is native to the southeast foothills of Himalaya prior to experience the species radiation in the end of Miocene era and then spread over tropical and subtropical regions worldwide (Wu et al., 2018). One of citrus species that is highly widespread in Southeast Asia, including Indonesia (Araujo et al., 2003) is kaffir lime (Citrus hystrix DC). De Candolle (DC) brought the seed of this lime from Mauritius and then classified it as the first species of papeda sub genus so that he called this lime as Mauritius papeda in 1824 (Swingle and Reece, 1967). This lime is also known by various names in its native area such as jeruk purut in Indonesia, kabuyaw in Philipinnes, limau purut in Malaysia, makrut in Thailand and truc in Vietnam (Wongpornchai, 2012).

Although the kaffir lime is not as popular as mandarin, oranges or pummelo, it still has a commercial value to be developed worldwide, because its fragrant leaves can be commercialized as spices and essential oils (Toawatana et al., 2006; Khoe and Mi, 2015; Budiarto, 2018; Budiarto et al., 2019). Various potential of kaffir lime utilization should be followed with efforts to develop plant production. Unfortunately, there is no such reports due to the current status of kaffir lime as minor citrus that is apparently wild in much of central Malesia region (Mabberley, 2004) or even grow naturally by some villagers in their own backyard (Wongpornchai, 2012; Irsyam, 2015). To gain the leaf production, the kaffir lime should be intensively cultivated. The proposing agricultural inputs for leaf-oriented lime culture are shading and pruning, since two mentioned practices are frequently reported as plant growth regulation techniques.

Shading is one of culture techniques to reduce the sunlight exposure, air temperature and also evapotranspiration but increase the air relative humidity in the agroecosystem (Alarcon et al., 2006). In general, the reduction of

\footnotetext{
${ }^{*}$ Corresponding author:

Roedhy Poerwanto, Department of Agronomy and Horticulture, Bogor Agricultural University, Indonesia, Center for Tropical Horticulture Studies, Bogor Agricultural University, Indonesia. E-mail: roedhy8@yahoo.co.id
} 
sunlight exposure on shaded plants is estimated for about $15-39 \%$, air temperature for about $2.3-2.5 \%$ and evapotranspiration for about $17-50 \%$, followed with the improvement of air relative humidity for about $2-21 \%$; however, it is highly influenced by the climatic region, shading structure, shading net type and also plant canopy (Mahmood et al., 2018).

Shading affect the plant growth and final yield either positive or negative, depending on the shading levels and plant sensitivity. Shading levels needs a lot of consideration in order to have beneficial stress, instead of harmful ones. Several negative effects of shading are delay the flowering of pineapple (Lin et al., 2015), lower the leafy production (Kosma et al., 2013), decline dry matter accumulation, flower and pod number of soybean (Bing and De-Ning, 2015; Bing et al, 2015), impede the apple fruit growth rate (Morandi et al., 2011), drop the fruit production and individual fruit size of lemon (GarciaSanchez et al., 2015). In contrary, beneficial effect of shading is also proved, i.e. the improvement of pitaya fruit color and also reduction of sunburn incidence (Chang et al., 2016), boosting the vegetative growth of several indigenous vegetables (Ekawati et al., 2010). Tolerant tomato varieties able to enlarge the fruit size by $7 \%$, as the consequences of moderate shading, lower than $50 \%$ (Baharuddin, 2014).

Pruning is one of agriculture practices to control the plant growth, reduce the pest attack occurrence and also improve the effectiveness of horticultural management (Morales and Davies, 2000; Gilman and Black, 2011, Fake, 2012). For fruit-oriented production, pruning used to reduce the excessive vegetative growth, overcome alternate bearing habits and improve the fruit quality, while for ornamental plants pruning aimed to enhance the aesthetic quality of the plant (Joubert et al., 2000; Marini, 2014). Pruning is also capable to delay the flower induction (Budiarto, 2018) and also increases the number of leaves in young mandarin trees by 2 -fold greater than unpruned ones (Septirosya, 2016).

Both shading and pruning treatment have been widely used individually in the number of fruit-oriented Citrus species, such as in acid lime (Ingle et al., 2001), grapefruit citrus (Sharma et al., 2007), lemon (Garcia-Sanchez et al., 2015; Gimeno et al., 2015), mandarin citrus (Singh et al., 2016), orange (Joubert et al., 2000), ponkan tangerine (Lee et al., 2015) and tangelo citrus (Morales and Davies, 2000). However, it has not been clearly reported on the leaf-oriented citrus species alike kaffir lime. Therefore, this article aimed to evaluate the agronomical and physiological characters of kaffir lime seedling under artificial shading and pruning for improving leaf production.

\section{MATERIALS AND METHODS}

The experiment was conducted in Pasir Kuda experimental farm of Bogor Agricultural University, Indonesia during the rainy season, November 2017 to March 2018. The latitude, longitude and altitude of the farm were -6.609042, 106.783605 and 263 meters above sea level, respectively. The soil of the farm was classified as latosol with clay texture. Soil $\mathrm{pH}$ was around $6.75 \pm 0.46$. Soil moisture was depended on surface water especially rainfall. Irrigation was not applied during the experiment due the abundance of rainfall. During the experiment, monthly rainfall was ranged from $135.7 \mathrm{~mm}$ up to $339.3 \mathrm{~mm}$ (with an average of $219.6 \mathrm{~mm})$.

Five-month-old kaffir lime seedlings grafted on Rangpur lime rootstock variety was used as plant material. All seedlings were disease free and relatively uniform in height and the number of leaves, i.e. $60 \mathrm{~cm}$ and 30 leaves, respectively. The seedling was arranged in nested design with two factors, namely shading and pruning. The first factor was shading that consisted of three levels, i.e. without shading (control), mild shading and moderate shading. Shading condition was created artificially by covering the shading frame ( $4 \mathrm{~m} \times 1 \mathrm{~m} \times 2 \mathrm{~m})$ using black net (Surya, Indonesia) obtained from local market in Bogor, Indonesia. The net was set only to the roof for creating the mild shading treatment, while moderate shading meant the net fully covered the frame. The second factor was pruning that nested inside the first factor and consisted of two levels, i.e. control and pruning. Pruning, in form of pinching, was done by removing the upper shoots of the seedling. In average, the removed shoot consisted of six leaves or $20 \%$ of the total leaf number. In short, there were six combination treatments and replicated eight times for every treatment, so that was totally 48 seedlings evaluated in present experiment.

The experiment was started in November 1, 2017 with soil tillage operating manually by using a hoe. Seedlings were transplanted from the polybag into the land with spacing about $50 \mathrm{~cm} \times 50 \mathrm{~cm}$ in November 15, 2017 . The transplanted plants started to be exposed by artificial shading in December 1, 2017. Fertilizers at rate of $20 \mathrm{~g} \mathrm{~N}$, $15 \mathrm{~g} \mathrm{P}_{2} \mathrm{O}_{5}$ and $10 \mathrm{~g} \mathrm{~K}_{2} \mathrm{O}$ were applied for individual lime through soil drench in December 15, 2017. Insecticide (Curacron, Indonesia) at rate of $1 \mathrm{ml}$ per 1000 liter water were routinely sprayed once a month. Weeding was applied once a month manually by hand. Plant maintenance was carried out until the harvesting season, which was three months after treatment in the early March.

Microclimates variables such as the light intensity, the estimation of light reduction, the ambient temperature, soil 
temperature and relative humidity were directly measured inside the shading frame once a week. The light intensity was measured at 01:00 p.m. in the sunny day by a Lux-28 portable digital lux meter (Danoplus, China) at the position of $10 \mathrm{~cm}$ above the apical bud of the plant (Lp) and above the soil surface below the plant canopy (Lb). The intercepted light $(\mathrm{Li})$ was determined by formula, i.e. $\mathrm{Li}=$ $\mathrm{Lp}-\mathrm{Lb}$. The light reduction ( $\mathrm{Lr}$ ) was estimated by formula, i.e. $\mathrm{Lr}=100 \mathrm{x}(\mathrm{Lc}-\mathrm{Ls}) / \mathrm{Lc}$. Lc was the light intensity in control treatment, while Ls was the light intensity in shading treatment. The ambient temperature and relative humidity were observed by thermo-hygrometer (Elitech, China). Soil temperature were measured by 4 -in-1 soil survey instrument (Amtast, China). Additional microclimate variables such incoming radiation and leaf temperature were derived from Li-6400XT observation on 90 days after treatments (DAT).

Agronomical characters such as growth performances and plant production were mainly observed during the experiment. Growth performances such plant height, shoot number, leaf number, stem diameter, root volume, plant growth rate and dry biomass accumulation rate were measured at 90 DAT. Plant height could be measured with a ruler from the base of the stem above the soil up to the highest apical bud. The number of shoots and leaves were counted with a hand counter (Kenko, Jepang). Individual leaf area and leaf weight were measured with a Li-3000C portable leaf area meter (Licor Inc, USA) and analytical balance (Hwh, China), respectively. Stem diameter was measured with a digital calliper (Nankai, China). Root volume was obtained from the additional value of water inside the beaker glass after the dipped of root biomass. The rate of plant growth and dry biomass accumulation were calculated from the increasing amount of fresh weight and dry weight of the entire plants (comparing pre- to posttreatments) divided by the number of weeks needed, i.e.12 observed weeks. The production of leaf, stem, root and entire plant were calculated from the fresh weight of each detached parts. Harvesting index (HI) was calculated by dividing the fresh weight of detached parts into the entire plant, so do the dry biomass partition (DBP) with the dry weight basis. To obtain dry weight and the water content, the samples were dehydrated in oven at $80^{\circ} \mathrm{C}$ for three days.

Physiological responses in form of photosynthetic rate, transpiration rate, stomatal conductance and leaf temperature were measured by using a Li-6400XT portable photosynthesis system (Licor Inc, USA) at 9:00 to 10:00 a.m. in the sunny morning of March 12018 or 90 DAT. Water use efficiency (WUE) was the ratio of photosynthetic rate to transpiration rate (Tuba et al., 1996). This measurement was involved four individual plants as replications for each combination treatment. For every plant, there were three leaves measured. The selected leaves were green, disease-free and fully developed that located at the $5^{\text {th }}$ and $6^{\text {th }}$ position below the dormant apical bud.

Leaf pigments including anthocyanin, chlorophyll $\mathrm{A}$ and B were observed on 60 DAT, based on Sims and Gamon (2002). The leaf sample was fully developed and normal leaves that produced after the treatment, specifically at the $5^{\text {th }}$ and $6^{\text {th }}$ position below the dormant apical bud. The samples were directly packed into the cool box and transferred to laboratory. Fresh leaves weighing 0.02 grams were mashed with $2 \mathrm{ml}$ acetris (85\% aceton plus $1 \%$ tris) solution, and then centrifuged at $6000 \mathrm{rpm}$ for 10 minutes. The supernatant as much as $1 \mathrm{ml}$ was added with $3 \mathrm{ml}$ of acetris for further mixed (Vortex, USA). Those solution was ready for absorbance measurement. The measurement was made at four wavelengths i.e. $470 \mathrm{~nm}, 537 \mathrm{~nm}, 647 \mathrm{~nm}$ and $663 \mathrm{~nm}$ by using a spectrophotometer. The pigment contents were further calculated by following equations.

1. Anthocyanin $=0.08173 \times \mathrm{A} 537-0.00697 \mathrm{x}$ A647 - $0.002228 \times \mathrm{A} 663$

2. Chlorophyll $\mathrm{A}=0.01373 \times \mathrm{A} 663-0.00089 \mathrm{x}$ A537- $0.003046 \times$ A 647

3. Chlorophyll $\mathrm{B}=0.02405 \times \mathrm{A} 647-0.004305 \mathrm{x}$ A537 - $0.005507 \times$ A663

4. Total Chlorophyll $=$ Chlorophyll A + Chlorophyll B

Leaf anatomy was also observed at 90 DAT using BX 51 light microscope (Olympus, Japan) calibrated on December 10, 2010, equipped with a 100x total magnification and integrated with DP2-BSW software computer to ease the anatomical measurement. The sample was prepared from fully developed, normal and damaged free kaffir lime leaf at the $7^{\text {th }}$ position below the dormant apical bud. For every treatment, there were 3 leaves collected from 3 individual plants. All leaves were further processed by slicing a small part near the midrib of upper leaflet forming a small cube with a size of $0.5 \times 0.5 \mathrm{~cm}$. The sliced cube was transferred into object glass (Sail, China) and ready to be observed inside the light microscope. The object of measurement were the thickness of leaf and leaf composing tissue (um), including upper epidermal tissue, upper palisade, sponges, oil glands, lower palisade and lower epidermal tissue.

Analysis of variance was performed by using Statistical Analysis Software (SAS) version 9.4. For any significant differences between treatments was evaluated by Duncan Multiple Range Test (DMRT) at level of confident 5\%.

\section{RESULTS AND DISCUSSION}

\section{Microclimates variation}

Microclimate conditions surrounding the treated kaffir lime were significantly affected by shading treatment 
(Table 1). The direct effect of shading was the reduction of light intensity for about $24 \%$ in mild shading and $43 \%$ in moderate ones. The indirect effect was the reduction of ambient temperature for about $1.9-3.3^{\circ} \mathrm{C}$, the reduction of leaf temperature for about $0.3-0.8^{\circ} \mathrm{C}$, the reduction of soil temperature for about $2.3-4.3^{\circ} \mathrm{C}$ and the improvement of relative humidity for about $2-2.4 \%$, compared to control. Microclimates modification through shading may have an effect on the plant production and quality (Mahmood et al., 2018). In agreement with previous work, present study also proved the difference growth, production and physiological response of kaffir lime in response to shading.

\section{Growth performances}

The growth of kaffir lime was improved by shading and pruning treatment (Table 2). Shading had a significant effect on plant growth rate, dry biomass accumulation rate, plant height, leaf number, stem diameter and root volume. Plant growth rates increased $89 \%$ in mild shading and $79 \%$ in moderate ones, compared to control. The rate of dry biomass accumulation and the height of plants increased $210 \%$ and $42 \%$ in both shading treatments, respectively. The leaf number of mild and moderate shaded lime were $38 \%$ and $35 \%$ greater than control, respectively. As compared to the control, mild shaded lime had $20 \%$ bigger stem and $74 \%$ bigger root, while moderate shaded ones had 13\% bigger stem and 69\% bigger root. Mild shading tended to be a slightly better than moderate ones in term of plant growth booster, however, both treatments were not significantly different in all variables, except the stem diameter. Shading solely was proved to be vegetative booster in numerous Citrus species, such as lemon (Gimeno et al., 2015), oranges (Incesu et al., 2016) and grapefruit (Cohen et al., 2005). Beneficial effect of shading in Citrus might be related to the status of its species as C3 plant (Sage and Zhu, 2011), since shading was inauspicious for C4 plants (Mahmood et al., 2018).

In other hand, pruning treatment significantly affected the height and the number of shoots of lime. The height of pruned plants was $8 \%$ lower than the unpruned ones since the detached amount of shoot at the initial time. The reduction of plant height could be useful to ease the plant maintenance and leaf harvesting activity. Pruning could increase almost $20 \%$ of the number of shoots of kaffir lime. The greater shoot number on pruned kaffir lime caused by the reduction of apical dominance as the shoot apical was pinched. Manual or chemical treatment to reduce the apical dominant was successfully proved to stimulate rapid new flush growth in several citrus (Sharma et al., 2007; Aliyah et al., 2015; Singh et al., 2016), since the plant wanted to immediately restore the lost foliage (Phillips, 1978). The greater shoot number, the higher potential for plant to have more leaf. Although it was not significantly different, the pruned lime tended to have more leaves than unpruned ones.

Pruning was not significantly affected the area of and weight of individual leaf of kaffir lime (Table 3). Plant response to pruning was varied depend upon the pruning level applied. Heavy pruning in form of removal the entire existing canopy of 4-year-old mandarin citrus caused the decline of source capacity so the plant was only able to produce the smaller leaf size than the unpruned ones (Budiarto, 2018). Yuan et al. (2005) also reported that defoliation, another term of pruning with relatively similar

Table 1: Microclimate variation under different shading treatments during study period

\begin{tabular}{lccc}
\hline Microclimates & Control & Mild shading & Moderate shading \\
\hline 1. Light intensity $(\times 1000$ lux $)$ & $152.21 \pm 2.68 \mathrm{a}$ & $115.80 \pm 3.84 \mathrm{~b}$ & $86.59 \pm 3.75 \mathrm{c}$ \\
2. Incoming radiation $\left(\mathrm{W} \mathrm{m}^{-2}\right)$ & $160.11 \pm 0.10 \mathrm{a}$ & $159.96 \pm 0.16 \mathrm{~b}$ & $159.81 \pm 0.05 \mathrm{c}$ \\
2. Ambient temperature $\left({ }^{\circ} \mathrm{C}\right)$ & $29.50 \pm 0.93 \mathrm{a}$ & $27.63 \pm 1.06 \mathrm{~b}$ & $26.25 \pm 0.71 \mathrm{c}$ \\
3. Leaf temperature $\left({ }^{\circ} \mathrm{C}\right)$ & $29.03 \pm 0.30 \mathrm{a}$ & $28.70 \pm 0.51 \mathrm{~b}$ & $28.21 \pm 0.39 \mathrm{c}$ \\
4. Soil temperature $\left({ }^{\circ} \mathrm{C}\right)$ & $34.50 \pm 0.71 \mathrm{a}$ & $32.25 \pm 0.46 \mathrm{~b}$ & $30.25 \pm 0.71 \mathrm{c}$ \\
5 5. Ambient relative humidity $(\%)$ & $71.63 \pm 1.77 \mathrm{~b}$ & $73.63 \pm 1.06 \mathrm{a}$ & $74.00 \pm 1.20 \mathrm{a}$ \\
\hline
\end{tabular}

Means in the same row followed by different alphabets are significantly different based on DMRT at $\alpha 5 \%$.

Table 2: Growth performance of kaffir lime in response to shading and pruning at 90 DAT

\begin{tabular}{|c|c|c|c|c|c|c|c|}
\hline Treatments & $\begin{array}{l}\text { Plant growth rate } \\
\left(\mathrm{g} \text { week }^{-1}\right)\end{array}$ & $\begin{array}{l}\text { Dry biomass accumulation } \\
\left(\mathrm{g} \mathrm{week}^{-1}\right)\end{array}$ & No. shoot & $\begin{array}{c}\text { Plant } \\
\text { height }(\mathrm{cm})\end{array}$ & No. leaf & $\begin{array}{c}\text { Stem } \\
\text { diameter }(\mathbf{c m})\end{array}$ & $\begin{array}{c}\text { Root } \\
\text { volume }(\mathrm{ml})\end{array}$ \\
\hline \multicolumn{8}{|l|}{ Shading } \\
\hline No & $5.53 \pm 0.40 \mathrm{~b}$ & $1.20 \pm 0.35 b$ & $4.25 \pm 0.50$ & $70.9 \pm 2.3 b$ & $75.8 \pm 2.5 b$ & $0.98 \pm 0.02 \mathrm{c}$ & $14.86 \pm 1.62 \mathrm{~b}$ \\
\hline Mild & $10.21 \pm 0.35 a$ & $3.80 \pm 0.45 a$ & $4.38 \pm 0.54$ & $101.1 \pm 2.7 a$ & $104.6 \pm 5.9 a$ & $1.18 \pm 0.02 a$ & $25.86 \pm 1.25 a$ \\
\hline Moderate & $9.88 \pm 0.59 a$ & $3.65 \pm 0.40 a$ & $4.50 \pm 0.82$ & $100.4 \pm 3.1 \mathrm{a}$ & $102.0 \pm 2.7 a$ & $1.11 \pm 0.02 b$ & $25.13 \pm 1.40 \mathrm{a}$ \\
\hline \multicolumn{8}{|l|}{ Pruning } \\
\hline No & $8.31 \pm 0.50$ & $3.09 \pm 0.40$ & $4.00 \pm 0.61 b$ & $94.8 \pm 2.5 a$ & $92.2 \pm 3.5$ & $1.09 \pm 0.02$ & $21.17 \pm 1.34$ \\
\hline Pruning & $8.77 \pm 0.40$ & $3.20 \pm 0.40$ & $4.75 \pm 0.63 a$ & $86.8 \pm 2.4 b$ & $96.1 \pm 3.4$ & $1.09 \pm 0.02$ & $22.75 \pm 1.50$ \\
\hline CV (\%) & 3.54 & 6.61 & 13.99 & 2.11 & 3.7 & 1.45 & 4.59 \\
\hline
\end{tabular}

Means in the same column followed by different alphabets are significantly different based on DMRT at $\alpha 5 \%$; CV-coefficient of variation. 
meaning, should not exceed $25 \%$ of the total canopy in order to prevent the negative impact on leaf size, canopy growth, fruit yield and quality. It was likely that citrus was sensitive to leaf disturbance, so the pruning level should be adjusted to be lighter in order to have beneficial stress instead of harmful ones. Therefore, present study applied the light level of pruning since only $1 / 5$ of the seedling foliage removed.

In opposite to pruning, shading treatment was success to significantly enlarge the individual leaf size of kaffir lime (Table 3). The shaded lime had 27\% larger leaf than exposed lime. The enlargement of leaf surface is frequently happened under shaded condition as plant wanted to expand the sunlight harvesting area (Huxley, 1967, Levitt, 1980; Matsoukis et al., 2015). Plant grown on natural open environment maintained the leaf size in a very strict way

Table 3: Individual leaf size of kaffir lime in response to shading and pruning at 90 DAT

\begin{tabular}{lcc}
\hline Treatments & \multicolumn{2}{c}{ Individual leaf size } \\
\cline { 2 - 3 } & Leaf area $\left(\mathrm{cm}^{2}\right)$ & Leaf weight (gram) \\
\hline Shading & $18.38 \pm 0.35 \mathrm{~b}$ & $0.55 \pm 0.01 \mathrm{~b}$ \\
No & $23.32 \pm 0.70 \mathrm{a}$ & $0.70 \pm 0.02 \mathrm{a}$ \\
Mild & $23.49 \pm 0.90 \mathrm{a}$ & $0.71 \pm 0.03 \mathrm{a}$ \\
$\quad$ Moderate & & \\
Pruning & $22.14 \pm 0.60$ & $0.66 \pm 0.02$ \\
No & $21.33 \pm 0.73$ & $0.64 \pm 0.02$ \\
Pruning & 1.72 & 2.01 \\
CV (\%) &
\end{tabular}

Means in the same column followed by different alphabets are significantly different based on DMRT at $\alpha 5 \%$; CV-coefficient of variation. to keep the balance of sink and source. The greater leaf area on the exposed lime was beneficial for the growth; however, it showed the greater transpiration (Zlatev and Lidon, 2012). Under shading treatment, the transpiration is minimized so the water loss due to the greater leaf area could be managed properly. Shading produced not only a larger leaf but also a heavier leaf with a significant improvement by $28 \%$ compared to exposed lime. This finding might be associated with the absence of significant reduction on leaf thickness.

Pruning treatment was not show any significant effect on the thickness of individual leaf and its constituent tissues, so did the shading (Table 4). However, there was a tendency for the reduction in leaf thickness and its constituent tissues such as epidermal and palisade tissue, due to the artificial shading. Leaf thickness reduction was one of well-known adaptation strategy of plant under shading condition (Vogelman and Martin, 1993; Anderson et al.,1995; Taiz and Zeiger, 2002). A less thick of shaded leaves caused by underdevelopment of mesophyll cell was beneficial to minimize the cost of cell maintenance (Grecco et al., 2014).

\section{Plant production}

Production and estimated productivity of kaffir lime were also significantly affected by shading and pruning treatments (Table 5). The fresh weight of entire plant was significantly increased by shading for about $58 \%$ and pruning for about $4 \%$. The stem production also increased by $58 \%$ and $8 \%$ due to the shading and pruning, respectively. The leaf and

Table 4: The thickness $(\mu \mathrm{m})$ of individual kaffir lime leaf and its constituent tissues following shading and pruning at 90 DAT

\begin{tabular}{lccccccc}
\hline Treatments & Upper epidermis & Lower epidermis & Upper palisade & Lower palisade & Sponge & Oil gland & Total \\
\hline Shading & & & & & & & \\
No & $18.56 \pm 3.9$ & $22.48 \pm 4.8$ & $36.73 \pm 8.0$ & $83.30 \pm 8.1$ & $179.19 \pm 17.8$ & $149.91 \pm 28.4$ & $356.82 \pm 17.3$ \\
Mild & $16.69 \pm 2.4$ & $19.02 \pm 6.8$ & $32.40 \pm 7.8$ & $75.04 \pm 11.7$ & $168.74 \pm 21.3$ & $140.48 \pm 19.7$ & $326.67 \pm 20.7$ \\
$\quad$ Moderate & $15.52 \pm 4.6$ & $20.61 \pm 7.6$ & $34.24 \pm 2.1$ & $61.61 \pm 14.6$ & $182.81 \pm 21.3$ & $156.14 \pm 38.5$ & $328.54 \pm 24.9$ \\
Pruning & & & & & & & \\
No & $16.96 \pm 4.1$ & $22.5 \pm 4.7$ & $35.03 \pm 5.7$ & $72.37 \pm 12.8$ & $178.16 \pm 22.4$ & $144.63 \pm 19.1$ & $336.54 \pm 25.3$ \\
Pruning & $16.89 \pm 2.9$ & $18.9 \pm 8.1$ & $33.89 \pm 6.3$ & $74.26 \pm 10.2$ & $175.67 \pm 17.9$ & $153.05 \pm 38.6$ & $338.15 \pm 16.7$ \\
CV (\%) & 22.63 & 31.73 & 22.08 & 17.16 & 5.35 & 19.09 & 6.18 \\
\hline
\end{tabular}

Means in the same column followed by different alphabets are significantly different based on DMRT at $\alpha 5 \%$; CV-coefficient of variation.

Table 5: Production of kaffir lime following shading and pruning at 90 DAT

\begin{tabular}{|c|c|c|c|c|c|c|}
\hline \multirow[t]{2}{*}{ Treatments } & \multicolumn{4}{|c|}{ Production (g) } & \multicolumn{2}{|c|}{ Estimated Productivity(ton ha ${ }^{-1}$ ) } \\
\hline & Plant & Leaf & Stem & Root & Leaf & Stem \\
\hline \multicolumn{7}{|l|}{ Shading } \\
\hline No & $92.72 \pm 4.91 b$ & $40.98 \pm 1.16 c$ & $35.86 \pm 1.82 b$ & $15.88 \pm 2.15 b$ & $1.64 \pm 0.04 \mathrm{c}$ & $1.43 \pm 0.12 b$ \\
\hline Mild & $148.91 \pm 4.97 a$ & $66.78 \pm 1.59 a$ & $57.10 \pm 1.57 a$ & $25.04 \pm 2.13 a$ & $2.67 \pm 0.06 a$ & $2.28 \pm 0.10 a$ \\
\hline Moderate & $145.01 \pm 5.05 a$ & $63.73 \pm 1.44 b$ & $55.87 \pm 1.51 \mathrm{a}$ & $25.41 \pm 2.36 a$ & $2.55 \pm 0.05 b$ & $2.23 \pm 0.08 a$ \\
\hline \multicolumn{7}{|l|}{ Pruning } \\
\hline No & $126.10 \pm 5.14 b$ & $57.07 \pm 1.46$ & $47.67 \pm 1.74 b$ & $21.36 \pm 2.17$ & $2.28 \pm 0.49$ & $1.91 \pm 0.42 b$ \\
\hline Pruning & $131.66 \pm 4.81 \mathrm{a}$ & $57.26 \pm 1.33$ & $51.55 \pm 1.53 a$ & $22.86 \pm 2.26$ & $2.29 \pm 0.47$ & $2.06 \pm 0.39 a$ \\
\hline CV (\%) & 2.81 & 1.73 & 2.52 & 7.87 & 1.73 & 2.52 \\
\hline
\end{tabular}

Means in the same column followed by different alphabets are significantly different based on DMRT at $\alpha 5 \%$; CV-coefficient of variation. 
root fresh weight was more influenced by shading rather than pruning, with an increase of both variables by $59 \%$ compared to the exposed lime. Unlike the root, leaf and stem are two important commercialized parts of kaffir lime agribusiness in Indonesia. The leaf is mostly sold as cooking spices at a price of IDR $20,000 \mathrm{~kg}^{-1}$, while the stem is a post-harvest by-product that is bought by essential oil refineries as fuelwood at a price of IDR 1,000 $\mathrm{kg}^{-1}$ (Budiarto et al., 2019). The productivities of leaf and stem could be estimated by multiplying the individual yield with the number of plant population per ha (40,000 plants with a planting distance for about $50 \times 50 \mathrm{~cm})$. The greater the individual yield, the higher estimated productivity. Under shaded condition, the leaf productivity is increased by 0.97 ton $\mathrm{ha}^{-1}$. The improving production and hence estimated productivity on shaded lime was caused by the improving growth performances as previously reported. Similar finding on indigenous vegetables showed by Ekawati et al. (2010) that artificial shading able to double the yield of Talinum triangulare and to quadruple the yield of Pilea trinervia.

Both shading and pruning were not caused a significant difference on harvesting index, dry biomass partition and water content of each plant parts (data not shown). However, those variables were seemed to be altered when compared between pre- and post-treatment (Fig. 1). As

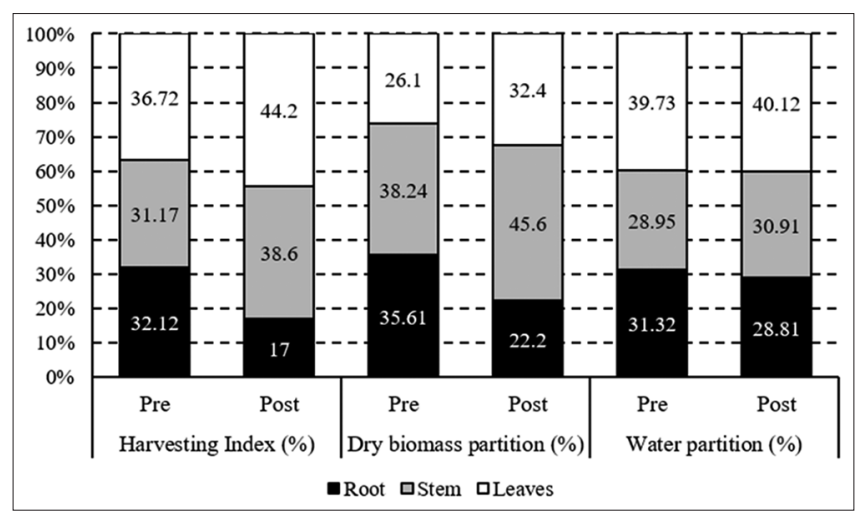

Fig 1. Percentage of harvesting index, dry biomass and water partition of kaffir lime at pre- and post-treatments. the running of time, the seedling would grow to be young plant that experienced an improvement of canopy growth more dominant than the root ones. Rapid canopy growth aimed to enlarge the source capacity of the plant. A less dominance of root was associated with the adequate of water surrounding the plant during the study period, i.e rainy season. The plant tended to boost the canopy growth rather than its roots under favourable conditions (Zlatev and Lidon, 2012). The stem became the most dominant part in term of dry biomass, with an increase of $7.4 \%$, compared to pre-treatment. Under favourable condition, it was common fact that the plant allocated a greater amount of biomass into the stem lead to the abundance lignocellulosic material in the stem for strengthening the plant structure.

\section{Plant photosynthesis}

Most of the physiological responses of kaffir lime were significantly affected by shading solely (Table 6). Although the shading screen had reduced the light intensity, it still sufficient for citrus leaves to reach maximum assimilation rates (Jifon and Syvertsen, 2003). There was a significant improvement in photosynthetic rate on shaded trees for about $13 \%$ than control. The higher photosynthetic rate on shaded lime is associated with better growth performances and subsequently plant production. This finding on kaffir lime was in agreement with previous studies on numerous Citrus species such as orange (Medina et al., 2002), grapefruit (Cohen et al., 2005), tangor citrus (Raveh et al., 2003) and lemon (Alarcon et al., 2006).

Moreover, shading could help the citrus leaf to avoid the incidence of photoinhibition. Photoinhibition is the reduction of solar energy conversion efficiency caused by the excessive photon absorption. The light saturation point for citrus is about $400 \mathrm{mmol} \mathrm{m} \mathrm{m}^{-2} \mathrm{~s}^{-1}$ (Syvertsen (1984). Exceeding the saturation point could promote the accumulation of unused excitation energy and then lead to photoinhibition. Previous studies reported that shaded leaves were less photoinhibited than sunlit leaves, leading to the higher photosynthetic efficiency (Jifon and Syvertsen, 2003).

Table 6: Physiological responses of kaffir lime following shading and pruning

\begin{tabular}{|c|c|c|c|c|}
\hline Treatments & $\begin{array}{c}\text { Photosynthetic } \\
\text { rate }\left(\mu \mathrm{mol} \mathrm{CO}_{2} \mathrm{~m}^{-2} \mathrm{~s}^{-1}\right)\end{array}$ & $\begin{array}{l}\text { Stomatal conductance } \\
\left(\mathrm{mol} \mathrm{H}_{2} \mathrm{O} \mathrm{m}^{-2} \mathrm{~s}^{-1}\right)\end{array}$ & $\begin{array}{l}\text { Transpiration rate } \\
\left(\mathrm{mmol} \mathrm{H}_{2} \mathrm{O} \mathrm{m}^{-2} \mathrm{~s}^{-1}\right)\end{array}$ & $\begin{array}{l}\text { Water use efficiency } \\
\left(\mu \mathrm{mol} \mathrm{CO} \mathrm{Cmol} \mathrm{H}_{2} \mathrm{O}^{-1}\right)\end{array}$ \\
\hline \multicolumn{5}{|l|}{ Shading } \\
\hline No & $28.93 \pm 2.45 b$ & $0.66 \pm 0.02 c$ & $10.56 \pm 0.02 a$ & $2.74 \pm 0.23 b$ \\
\hline Mild & $30.57 \pm 3.08 b$ & $0.69 \pm 0.05 b$ & $10.48 \pm 0.02 b$ & $2.92 \pm 0.30 \mathrm{~b}$ \\
\hline Moderate & $34.53 \pm 3.65 a$ & $0.73 \pm 0.04 a$ & $10.42 \pm 0.01 \mathrm{c}$ & $3.31 \pm 0.35 a$ \\
\hline \multicolumn{5}{|l|}{ Pruning } \\
\hline No & $30.68 \pm 2.89$ & $0.70 \pm 0.04$ & $10.47 \pm 0.01 b$ & $2.93 \pm 0.28$ \\
\hline Pruning & $32.01 \pm 3.23$ & $0.68 \pm 0.03$ & $10.50 \pm 0.02 a$ & $3.05 \pm 0.31$ \\
\hline CV (\%) & 9.98 & 6.44 & 0.08 & 10.05 \\
\hline
\end{tabular}

Means in the same column followed by different alphabets are significantly different based on DMRT at $\alpha 5 \%$; CV-coefficient of variation. 
Budiarto, et al.

Table 7: Leaf pigmen of kaffir lime following shading and pruning

\begin{tabular}{|c|c|c|c|c|c|}
\hline \multirow[t]{2}{*}{ Treatments } & \multicolumn{4}{|c|}{ Chlorophyll } & \multirow[t]{2}{*}{ Anthocyanin (mg $100 \mathrm{~g}^{-1}$ sample) } \\
\hline & $A\left(\mathrm{mg} \mathrm{g}^{-1}\right)$ & $B\left(\mathrm{mg} \mathrm{g}^{-1}\right)$ & $\mathrm{A} / \mathrm{B}$ & Total $\left(\mathrm{mg} \mathrm{g}^{-1}\right)$ & \\
\hline \multicolumn{6}{|l|}{ Shading } \\
\hline No & $1.33 \pm 0.031$ & $0.42 \pm 0.017 \mathrm{c}$ & $3.16 \pm 0.127 a$ & $1.75 \pm 0.034 b$ & $0.077 \pm 0.005 a$ \\
\hline Mild & $1.31 \pm 0.039$ & $0.49 \pm 0.014 b$ & $2.69 \pm 0.121 b$ & $1.79 \pm 0.040 \mathrm{ab}$ & $0.057 \pm 0.002 b$ \\
\hline Moderate & $1.30 \pm 0.051$ & $0.54 \pm 0.031 a$ & $2.41 \pm 0.184 c$ & $1.84 \pm 0.041 a$ & $0.055 \pm 0.008 b$ \\
\hline \multicolumn{6}{|l|}{ Pruning } \\
\hline No & $1.32 \pm 0.039$ & $0.48 \pm 0.021$ & $2.78 \pm 0.366$ & $1.80 \pm 0.034$ & $0.063 \pm 0.005$ \\
\hline Pruning & $1.30 \pm 0.042$ & $0.48 \pm 0.020$ & $2.73 \pm 0.349$ & $1.79 \pm 0.043$ & $0.062 \pm 0.006$ \\
\hline CV (\%) & 2.73 & 4.67 & 5.03 & 2.34 & 7.50 \\
\hline
\end{tabular}

Means in the same column followed by different alphabets are significantly different based on DMRT at $\alpha 5 \%$; CV-coefficient of variation.

The higher photosynthetic rate on shaded lime is resulted by the higher stomatal conductance. Stomatal conductance is a term for the rate of $\mathrm{CO}_{2}$ entering and water vapor exiting through the stomatal pore of the leaf. As the stomatal conductance increased, the $\mathrm{CO}_{2}$ concentrations at the chloroplasts also increased (Raveh et al., 2003). Present study confirmed that the shaded leaf stomatal conductance was $8 \%$ greater than exposed ones. Haijun et al. (2015) reported that the lower evaporative demand under shading condition facilitated the plant to improve the stomatal conductance and then photosynthetic rate.

Citrus plant was naturally exposed with transient water deficit at the midday and subsequently caused the lower stomatal conductance and also net assimilation rate (Alarcon et al., 2006). The reduction of direct radiation through shading treatment could help the plant to prevent the transient water deficit (Medina et al., 2002; Cohen et al., 2005), so that it can improve the integrated daily net $\mathrm{CO}_{2}$ uptake for about 20\% greater than the sunlit tree (Alarcon et al., 2006). The water deficit could be stimulated by the higher temperature during the midday that boost plant transpiration rate.

Both pruning and shading have significant effect on transpiration rate of kaffir lime (Table 6). Transpiration rate was significantly improved by pruning, while shading seemed to reduce it. More leaves produced by pruned lime was attributed to the higher transpiration. In opposite, lower transpiration on shaded tree was commonly reported because of the limited solar radiation lead to the alteration of microclimate surrounding the plant. Under moderate shading condition with $43 \%$ light reduction, the lower the temperature by $0.82^{\circ} \mathrm{C}$, the lower transpiration rate by $0.14 \mathrm{mmol} \mathrm{H}_{2} \mathrm{O} \mathrm{m}^{-2} \mathrm{~s}^{-1}$, compared to the control. The reduction of transpiration on shaded plant was followed with the improvement of water use efficiency (Nicolas et al., 2008). Our finding revealed that shaded lime had $14 \%$ greater water use efficiency than the control. It was in similar to previous study on young lemon by Alarcon et al., (2006).

\section{E. Leaf pigment}

Shading, rather than pruning, had a significant effect on the pigment content of kaffir lime leaves, except the chlorophyll A content (Table 7). Shading treatments significantly increased the chlorophyll B and total chlorophyll content by $23 \%$ and $4 \%$, but it was also decreased the ratio of chlorophyll A to B and anthocyanin content by $19 \%$ and $38 \%$, respectively. The higher the shading level tested in present study, the greater the value of chlorophyll B and total chlorophyll, the lower the content of accessory pigments such anthocyanins. Previous study on Ponkan citrus also showed similar finding (Grecco et al., 2014).

A higher chlorophyll B content, followed with lowering the ratio of chlorophyll A to B, was indicator of plant strategy adapted to the shading, since the enhancement of the size of the second photosystem antennas lead to have a more efficient photosynthesis and also reduce the photodamage resulted (Hoober and Eggnik, 2001; Pattanayaka et al., 2005; Yamasato et al., 2005). The reduction of anthocyanins content was aimed to enhance the light harvesting efficiency (Levitt, 1980) because sometime this pigment able to impede the running of photosynthesis by its accumulation in vacuoles of epidermis tissue (Sopandie, 2013). Our finding was also in agreement with Kosma et al. (2013) who stated that the higher pigment content on shaded plant was associated to better grana development, more chloroplasts, more chlorophylls per chloroplast as efficient plant adaptation strategy under the shading.

\section{CONCLUSION}

Kaffir lime seedling experienced better growth performances under shading condition that indicated by the improvement of plant growth by $84 \%$, dry biomass accumulation by $210 \%$, leaf number by $37 \%$, stem diameter by $17 \%$, root volume by $72 \%$, leading to better leaf production by $59 \%$ than unshaded ones. Pruning was significantly increased the shoot number by $20 \%$, however it showed no significant improvement of leaf production, as shading did. Individual leaf size was increased by shading, while pruning seemed 
to have no effect. Shaded lime growth improvement was attributed to the increase of photosynthetic rate, stomatal conductance, water use efficiency by $13 \%, 8 \%$ and $14 \%$ greater than the control, respectively. Shaded leaves showed greater chlorophyll B by $23 \%$, lower anthocyanin by $38 \%$ than unshaded ones, indicated the physiological adaptation strategy to have a more efficient photosynthesis under shaded condition. Mild shading with $24 \%$ light reduction is highly recommended rather than moderate shading with $43 \%$ light reduction because it sounds more effective and efficient to boost the leaf production of kaffir lime seedling.

\section{ACKNOWLEDGEMENT}

This work was supported by The Republic of Indonesia under PMDSU Research Grant financial year 2018 (no. 1520/IT3.11/ PN/2018).

\section{Authors' contribution}

R.B. and R.P. planned the experiment. R.B. carried out the experiments. E.S. improved the number of variables observed. D.E. contributed to field management. R.B and R.P. wrote the manuscript by considering critical feedbacks from E.S., D.E. and A.A.

\section{REFERENCES}

Alarcon, J. J., M. F. Ortuno, E. Nicolas, A. Navarro and A. Torrecillas. 2006. Improving water-use efficiency of young lemon trees by shading with aluminised-plastic nets. Agric. Water Manag. 82: 387-398.

Aliyah, M., S. Susanto, D. Sukma and S. W. Ardie. 2015. Performance improvement of young pummelo citrus (Citrus maxima (Burm.) Merr.) by strangulation application and pinching. Asian J. Agric. Res. 9: 77-83.

Anderson, J. M., W. S. Chow and Y. I. Park. 1995. The grand design of photosynthesis acclimation of the photosynthetic apparatus to environmental cues. Photosynthesis Res. 46: 129-139.

Araujo, E. F. D., L. P. D. Queiroz and M. A. Machado. 2003. What is citrus? Taxonomic implications from a study of $\mathrm{cp}$-DNA evolution in the tribe Citreae (Rutaceae subfamily Aurantioideae). Divers. Evol., 3, 55-62.

Baharuddin, R. 2014. Shade Tolerance of 20 Genotypes of Tomato (Lycopersicon esculentum Mill). (Master Thesis). Bogor Agricultural University, Bogor.

Bing, L. and Q. De-Ning. 2015. Effects of shading on spatial distribution of flower and flower abscission in field-grown three soybeans in Northern China. Emir. J. Food Agric. 27: 629-635.

Bing, L., Q. De-Ning and Z. Xiao-Mei. 2015. The shoot dry matter accumulation and vertical distribution of soybean yield or yield components in response to light enrichment and shading. Emir. J. Food Agric. 27: 258-265.

Budiarto, R. 2018. Morphological and Metabolites Diversity, and Canopy Manipulations on Indonesian Citrus. (Master Thesis). Bogor Agricultural University, Bogor.

Budiarto, R., R. Poerwanto, E. Santosa, D. Efendi and A. Agusta.
2019. Preliminary study on production, post-harvest and marketing of kaffir lime (Citrus hystrix DC) in Tulungagung, Indonesia. J. Trop. Crop. Sci. 7: 2-9.

Chang, P. T., C. C. Hsieh and Y. L. Jiang. 2016. Responses of 'Shih Huo Chuan' pitaya (Hylocereus polyrhizus (Weber) Britt. and Rose) to different degrees of shading nets. Sci. Hortic. 198: 154-162.

Cohen, S., E. Raveh, Y. Li, A. Grava and E. E. Goldschmidt. 2005. Physiological responses of leaves, tree growth and fruit yield of grapefruit trees under reflective shade screens. Sci. Hortic. 107: 25-35.

Ekawati, R., A. D. Susila and J. G. Kartika. 2010. The effect of shade on growth and productivity of several indigenous vegetables. J. Hortic. Indones. 1: 46-52.

Fake, C. 2012. Pruning Citrus. California: University California Cooperative Extension Available from: http://www.ucanr.edu/ sites/placernevadasmallfarms/files/134946.pdf. [Last accessed on 2018 Mar 22].

García-Sánchez, F., I. Simón, V. Lidón, F. J. Manera, S. Simón-Grao, J. G. Pérez-Pérez and V. Gimeno. 2015. Shade screen increases the vegetative growth but not the production in 'Fino 49' lemon trees grafted on Citrus macrophylla and Citrus aurantium L. Sci. Hortic. 194: 175-180.

Gilman, E.F. and R. J. Black. 2011. Pruning Landscape Trees and Shrubs. University of Florida, Florida, US.

Gimeno, V., I. Simon, V. Martínez, V. Lidón, M. A. Shahid and F. Garcia-Sanchez. 2015. Effect of shade screen on production, fruit quality and growth parameters of 'Fino 49' lemon trees grafted on Citrus macrophylla and sour orange. Acta Hortic. 1065: 1845-1852.

Grecco, E. D., L. F. V. Silveira, V. L. D. Lima and J. E. M. Pezzopane. 2014. Ecophysiological aspects of sun and shade leaves of Ponkan tangerine (Citrus reticulata Blanco). Idesia, 32, 113-117.

Haijun, L., S. Cohen, J. H. Lemcoff, Y. Israeli and J. Tanny. 2015. Sap flow, canopy conductance and microclimate in a banana screenhouse. Agric. Forest Meteorol. 201: 165-175.

Hoober, J. K. and L. L. Eggink. 2001. A potential role of chlorophylls $\mathrm{b}$ and $\mathrm{c}$ in assembly of light-harvesting complexes. FEBS Lett. 489: $1-3$.

Huxley, P. A. 1967. The effects of artificial shading on some growth characteristics of arabica and robusta coffee seedlings, the effects of shading on dry weight, leaf area and derived growth data. J. Appl. Ecol. 4: 291-308.

Incesu, M., T. Yeşiloğlu, B. Çimen and B. Yılmaz. 2016. Effects of nursery shading on plant growth, chlorophyll content and PSII in 'Lane Late' navel orange seedlings. Acta Hortic. 1130: 301-305.

Ingle, I. V., R. B. Athawale, G. S. Tayde and G. B. Pakhare. 2001. Effect of severity and time of pruning on flower type fruit set and fruit retention in old acid lime trees (Citrus aurantifolia). Agric. Sci. Dig. 21: 65-66.

Irsyam, A. S. D. 2015. Floristic Study on Rutaceae of Madura. (Master Thesis). Bogor Agricultural University, Bogor.

Jifon, J. L. and J. P. Syvertsen. 2003. Moderate shade can increase net gas exchange and reduce photoinhibition in citrus leaves. Tree Physiol. 23: 119-127.

Joubert, F. J., M. H. Du Plessis and P. J. C. Stassen. 2000. Pruning strategies to alleviate overcrowding in higher density citrus orchards. J. Appl. Hortic. 2: 1-5.

Khoe, L. T. and T. V. Mi. 2015. Early evaluation of compatibility between commercial citrus varieties and kaffir lime (Citrus hystrix) and carrizo citrange (C. sinensis Osb. x P. trifoliata L. Raf.) rootstocks at Mekong delta, Vietnam. Int. J. Adv. Sci. Eng. 
Inf. Technol. 5: 323-328.

Kosma, C., V. Triantafyllidis, A. Papasavvas, G. Salahas and A. Patakas. 2013. Yield and nutritional quality of greenhouse lettuce as affected by shading and cultivation season. Emir. J. Food Agric. 25: 974-979.

Kozlowski, T. T., P. J. Kramer and S. G. Pallardy. 1997. Physiology of Woody Plants. Academic Press, Cambridge, US.

Lee, T. C., P. J. Zhong and P. T. Chang. 2015. The effects of preharvest shading and postharvest storage temperatures on the quality of 'Ponkan' (Citrus reticulata Blanco) mandarin fruits. Sci. Hortic. 188: $57-65$.

Levitt, J. 1980. Response of Plants to Environmental Stress. Academic Press, New York, US.

Lin, M. T., A. M. Chen, T. S. Lin, C. S. Kuan, C. L. Lee and W. J. Yang. 2015. Prevention of natural flowering in pineapple (Ananas comosus) by shading and urea application. Hortic. Environ. Biotechnol. 56: 9-16.

Mabberley, D. J. 2004. Citrus (Rutaceae): A review of recent advances in etymology, systematics and medical applications. BLUMEA. 49: 481-498.

Mahmood, A., Y. Hua, J. Tanny and E. A. Asante. 2018. Effects of shading and insect-proof screens on crop microclimate and production: A review of recent advances. Sci. Hortic. 241: 241-251.

Marini, R. 2014. Physiology of Pruning Fruit Trees. Virginia Cooperative Extension, Virginia. Available from: http://www. pubs.ext.vt.edu/content/dam/ pubs ext vt edu/422/422-025/422025 pdf. [Last accessed on 2018 Mar 22].

Matsoukis, A., D. Gasparatos and A. Chronopoulou-Sereli. 2015. Mepiquat chloride and shading effects on specific leaf area and $\mathrm{K}, \mathrm{P}, \mathrm{Ca}, \mathrm{Fe}$ and $\mathrm{Mn}$ content of Lantana camara L. Emir. J. Food Agric. 27: 121-125.

Medina, C. L., R. P. Souza, E. C. Machado, R. V. Ribeiro and J. A. B. Silva. 2002. Photosynthetic response of citrus grown under reflective aluminized polypropylene shading nets. Sci. Hortic. 96: 115-125.

Morales, P. and F. S. Davies. 2000. Pruning and skirting affect canopy microclimate, yields and fruit quality of Orlando Tangelo. Hortscience. 35: 30-35.

Morandi, B., M. Zibordi, P. Losciale, L. Manfrini, E. Pierpaoli and L. C. Grappadelli. 2011. Shading decreases the growth rate of young apple fruit by reducing their phloem import. Sci. Hortic. 127: $347-352$

Moore, G. A. 2001. Oranges and lemons: Clues to the taxonomy of citrus from molecular markers. Trends Genet. 17: 536-540.

Nicolas, E., V. L. Barradas, M. F. Ortuno, A. Navarro, A. Torrecillas and J. J. Alarcon. 2008. Environmental and stomatal control of transpiration, canopy conductance and decoupling coefficient in young lemon trees under shading net. Environ. Exp. Bot. 63: 200-206.

Pattanayaka, G. K., A. K. Biswal, V. S. Reddy and B. C. Tripathy. 2005. Light-dependent regulation of chlorophyll b biosynthesis in chlorophyllide a oxygenase overexpressing tobacco plants. Biochem. Biophys. Res. Commun. 326: 466-471.

Phillips, R. L. 1978. Tree size control hedging and topping citrus in high-density plantings. Proc. Fla. State Hortic. Soc. 91: 43-46.

Raveh, E., S. Cohen, T. Raz, D. Yakir, A. Grava and E. E. Goldschmidt. 2003. Increased growth of young citrus trees under reduced radiation load in a semi-arid climate. J. Exp. Bot. 54: 365-373.
Sage, R. F. and Zhu, X. G. 2011. Exploiting the engine of C4 photosynthesis. J. Exp. Bot. 62: 2989-3000.

Septirosya, T. 2016. Prediction of Young Borneo Prima Mandarin Growth and Tree Architecture on Different Fertilizer Dosage and Pruning Form. (Master Thesis). Bogor Agricultural University, Bogor.

Sharma, S. D., M. Singh, E. K. Rawls and J. B. Jr. Taylor. 2007. Defoliation of citrus trees by diquat. Proc. Fla. State Hortic. Soc. 120: 120-126.

Sims, D. A. and J. A. Gamon. 2002. Relationship between leaf pigment content and spectral reflectance across a wide range of species, leaf structures and developmental stages. Remote Sens. Environ. 81: 337-354.

Singh, J., L. K. Dashora, P. Bhatnagar and B. Singh. 2016. Impact of pruning on rejuvenation of declining Nagpur mandarin (Citrus reticulata Blanco.) orchard. Indian J. Agrofor. 18: 53-57.

Swingle, W. T. and P. C. Reece. 1967. The botany of citrus and its wild relatives. In: Reuther, W., H. J. Webber and L. D. Batchelor (Eds.), The Citrus Industry. Vol. 1. University of California Press, Berkeley, US.

Sopandie, D. 2013. Plant Physiological Adaptation of Abiotic Stress in Tropical Agroecosystem. IPB Press, Bogor, ID.

Syvertsen, J. P. 1984. Light acclimation in citrus leaves. Part II: CO2 assimilation and light, water, and nitrogen use efficiency. J. Am. Soc. Hortic. Sci. 109: 812-817.

Taiz, L and E. Zeiger. 2002. Plant Physiology. Sinauer Associates Inc., Publishers, Massachusetts, US.

Toawatana, N. H., P. Chaiyamutti, K. Panthong, W. Mahabusarakam and V. Rukachaisinkul. 2006. Antioxidative and free radical scavenging activities of some plants used in Thai folk medicine. Pharm. Biol. 44: 221-228.

Tuba, Z., K. Szente, Z. Nagy, Z. Csintalan and J. Koch. 1996. Responses of $\mathrm{CO}_{2}$ assimilation, transpiration and water use efficiency to long-term elevated $\mathrm{CO}_{2}$ in perennial $\mathrm{C} 3$ xeric loess steppe species. J. Plant Physiol. 148: 356-361.

Vogelman, T. C. and G. Martin. 1993. The functional significance of palisade tissue: Penetration of directional versus diffuse light. Plant Cell Environ. 16: 65-72.

Wongpornchai, S. 2012. Kaffir lime leaf. In: Peter, K. V. (Ed.), Handbook of Herbs and Spices. $2^{\text {nd }}$ ed. Woodhead Publishing Limited, Cambridge, UK.

Wu, G. W., J. Terol, V. Ibanez, A. Lopez-Garcia, E. Perez-Roman, C. Borreda, C. Domingo, F. R. Tadeo, J. Carbonell-Caballero, R. Alonso, F. Curk, D. Du, P. Ollitrault, M. L. Roose, J. Dopazo, F. G. Gmitter, D. S. Rokhsar and M. Talon. 2018. Genomics of the origin and evolution of citrus. Nature. 554: 311-316.

Yamasato, A., N. Nagata, R. Tanaka and A. Tanaka. 2005. The terminal domain of chlorophyllide a oxygenase confers protein instability in response to chlorophyll $\mathrm{b}$ accumulation in arabidopsis. Plant Cell. 17: 1585-1589.

Yuan, R., F. Alferez, I. Kostenyuk, S. Singh, J. P. Syvertsen and J. K. Burns. 2005. Partial defoliation can decrease average leaf size but has little effect on orange tree growth, fruit yield and juice quality. Hortscience. 40: 2011-2015.

Zlatev, Z. and F. C. Lidon. 2012. An overview on drought induced changes in plant growth, water relations and photosynthesis. Emir. J. Food Agric. 24: 57-72. 